\title{
Marketing the Market: The Ideology of Market Mechanisms for Biodiversity Conservation
}

\author{
Jerneja Penca*
}

\begin{abstract}
The emergence of market mechanisms for the protection of biodiversity and ecosystem services in recent years has been portrayed by most conservation institutions and epistemological frameworks as an unprecedented opportunity for the conservation of nature. This article shifts the focus from the improved effectiveness arguments concerning such mechanisms to examine their institutional and political context and origins. It outlines the field of transnational biodiversity markets and engages with the normative biases it displays. The regulatory vocabulary of 'market mechanisms' is juxtaposed to the more explicit ideological approach professed by the critics of neoliberalism. The argument is that, rather than an inevitable component in contemporary conservation governance, market mechanisms imply a set of contested choices, for certain values, a particular economic-development trajectory, a particular understanding of the biodiversity problem, and a weak role for legal obligations. Transnational environmental law needs to re-establish its interest beyond that of the regulation literature if it is to account for the proliferating movements around the world in favour of a reasserted normative guidance for the markets and against the process of marketing the market.
\end{abstract}

Keywords: Biodiversity conservation, Market mechanisms, Regulatory choice, Neoliberalism, Transnational law

\footnotetext{
${ }^{*}$ European University Institute, Florence (Italy)

Email: jerneja.penca@eui.eu.

I am grateful to Karen Morrow and Guilherme Vasconcelos Vilaça for their thoughtful engagement with an earlier draft of this paper, and to the TEL editors and two anonymous reviewers for their valuable remarks.
} 


\section{INTRODUCTION}

International discourses on the conservation of nature have in recent years shown great enthusiasm for securing the improved effectiveness of measures. ${ }^{1}$ The sources of this fervour are to be found in the 'new' tools for managing and financing biodiversity - market mechanisms for biodiversity conservation, forming part of a broader reorientation of the context in favour of market approaches in environmental law. ${ }^{2}$ These regulatory tools are expected to 'increase the pace, expand the scope and improve the effectiveness of conservation', ${ }^{3}$ and have indeed already contributed to the 'growing feeling of Renaissance' 4 in a governance area that is characterized by ever more daunting statistics and indicators. ${ }^{5}$

However, the promises of the arrival of 'innovative' opportunities for biodiversity conservation have eclipsed a more critical exploration of their normative character. The lawyer's inroads into these structures have been largely limited to their design and smooth functioning, while taking their ideological and practical biases for granted. 6 A more careful inquiry into the values, principles and beliefs enshrined in these mechanisms has largely been missing, as has any engagement with the opposition to the concepts and processes of privatization, marketization and commodification, the expansion of the neoliberal creed and weakened democracy that underpin them. These are all contested categories and significant building blocks in normative depictions of the social space, but they all receive less attention in present legal debates about biodiversity conservation, focussing largely on effectiveness.

Contrary to the predominant legal approach to market mechanisms for biodiversity conservation, social geographers have generated a more heated debate about the same phenomena. In a fully blown research agenda on the 'neoliberalization of nature' they are grappling with the evidence of misuse of market mechanisms in practice and are attacking the

\footnotetext{
${ }^{1}$ E.g. UN GA Resolution A/RES/65/161 of 20 December 2011 (declaring the United Nations Decade on Biodiversity (2011-2020) as the timeframe for implementing the Strategic Plan for Biodiversity agreed in Nagoya Japan in October 2010). Available at: http://www.un.org/ga/search/view_doc.asp?symbol=A/RES/65/161.

2 K. Morrow, 'Rio +20, the Green Economy and Re-orienting Sustainable Development' (2012) 14(4)

Environmental Law Review, pp. 279-97.
}

3 Available at: http://willamettepartnership.org.

4 G. C. Daily \& P. A. Matson, 'Ecosystem Services: From Theory to Implementation' (2008) 105(28)

Proceedings of the National Academy of Sciences, pp. 9455-6, at 9455.

${ }^{5}$ E.g. A.D. Barnosky et al., 'Has the Earth's sixth mass extinction already arrived?' (2011) 471 Nature, pp. 51-7.

6 This article emerges form one such occasion, the conference on Regulatory and Institutional Frameworks for Markets for Ecosystem Services, held at the University of Surrey (UK) on 6-7 June 2012. Another example includes the workshop on Markets for biodiversity and ecosystem services, at Chatham House, London (UK), 29 Nov. 2011, organized by the Secretariat of the CBD and the UNEP World Conservation Monitoring Centre. 
phenomenon at its conceptual roots. ${ }^{7}$ It is not that environmental law scholars generally disregard political paradigms, however. They have taken seriously questions of compatibility of market liberalism and sustainability demands ${ }^{8}$ and are conversant with arguments from the philosophical and ethical opposition to the implementation of market mechanisms. ${ }^{9}$ At the intersection of sociology, environmental sciences and law, the trend of market scepticism has been manifested most clearly through evaluations of the carbon markets. ${ }^{10}$ However, the specific field of biodiversity conservation has been detached from the considerations of market mechanisms as biased tools. ${ }^{11}$

For the most part, the unproblematic and privileged position of markets is perpetuated by both the dominant epistemic position and governance trends. Markets are considered an inevitable and welcome component in contemporary governance and a solid form of authority, legitimized through the existence of 'market state' 12 and 'regulatory capitalism', 13 where regulation may constrain markets but not rule them out. Within the field of environmental law, the blindness to market ideology is strengthened by the presence of 'regulatory choice' scholarship. This framework has already been critiqued for misconceiving law as a conciliatory tool capable of

\footnotetext{
${ }^{7}$ See, e.g., the following themed/special issues: (2005) 16(1) Capitalism Nature Socialism, pp. 1-137; (2004) 35(3) Geoforum, pp. 269-394; (2010) 42(3) Antipode, pp. 469-799; (2012) 43(3) Geoforum, pp. 363-426

${ }^{8}$ See, e.g., D. Kysar, 'Sustainable Development and Private Global Governance' (2008) 83 Texas Law Review, pp. 2109-66; D.M. Driesen, 'Sustainable Development and Market Liberalism's Shotgun Wedding: Emissions Trading Under the Kyoto Protocol' (2008) 83(1) Indiana Law Journal, pp. 21-69; J. Dryzek, 'Ecology and Discursive Democracy: Beyond Liberal Capitalism and the Administrative State' (1992) 3 Capitalism, Nature, Socialism, pp. 18-42; D. Schweickart, 'Is Sustainable Capitalism an Oxymoron?' (2009) 8(2/3) Perspectives on Global Development and Technology, pp. 559-80.
}

${ }^{9}$ See, e.g., S. Kelman, What Price Incentives? Economists and the Environment (Auburn House, 1981); E. Anderson, Value of Ethics in Economics (Harvard University Press, 1993); M. Sagoff, The Economy of the Earth: Philosophy, Law, and the Environment (Cambridge University Press, 2008); M. J. Sandel, What Money Can't Buy: The Moral Limits of Markets (Allen Lane, 2012); J.O'Neill, A. Holland \& A. Light, Environmental Values (Routledge, 2008).

${ }^{10}$ See S. Böhm \& S. Dabhi (eds.), Upsetting the Offset: The Political Economy of Carbon Markets (Mayfly Books, 2009); P. Newell \& M. Paterson, Climate Capitalism: Global Warming and the Transformation of the Global Economy (Cambridge University Press, 2010); L. Lohmann, 'Uncertainty Markets and Carbon Markets: Variations on Polanyian Themes' (2010) 15(2) New Political Economy, pp. 225-54. G. Winter, 'The Climate is No Commodity: Taking Stock of the Emissions Trading System' (2010) 22(1) Journal of Environmental Law, pp. 1-25.

${ }^{11}$ See, e.g., OECD, Harnessing Markets for Biodiversity: Towards Conservation and Sustainable Use (OECD, 2003); B. Madsen, N. Carroll \& K. Moore Brands, State of Biodiversity Markets Report: Offset and Compensation Programs Worldwide (Ecosystems Marketplace, 2010).

${ }^{12}$ P. Bobbitt, The Shield of Achilles: War, Peace, and the Course of History (Anchor Books, 2002).

13 D. Levi-Faur, 'The Global Diffusion of Regulatory Capitalism' (2005) 598(1) The Annals of the American Academy of Political and Social Science, pp. 12-32, at 14. 
'fixing' environmental problems, ${ }^{14}$ denying that its role is rather at the conflict of discourses ${ }^{15}$ and in search of case-sensitive responses, instead of commonly applicable, 'meta' legal solutions. ${ }^{16}$ The image of law perpetuated through the 'regulatory choice' framework thus sustains the dominant positivist conception of law, inherently hostile to the idea of muddling the autonomy of formal rules with external social influences.

However, while the dominant epistemic frameworks may obfuscate the normative (ideological) dimension of environmental law, they do not excise it. In this article, my interest is to make the normative dimension explicit and to bring it into the open view of the legal audience. I do this by drawing on the approaches of non-legal disciplines and juxtaposing a legal conception of the on-going developments as 'market approaches' to the framing of these same processes in some of the non-legal literature, specifically that on 'neoliberal ideology'.

In this exercise, the emerging concept of 'transnational law' presents itself as a helpful analytical tool. I follow the view that it represents less a new substantive field of law than a methodology and approach to legal studies and practice. ${ }^{17}$ As such, transnational law represents a convenient but also reasonable shorthand for exploring law 'at the margins' - law that crosses jurisdictions, traditional definitions of authority and confines of the doctrinal legal discipline. The emergence of the denomination 'transnational (environmental) law' has not so much created new legal problems as it has accommodated some less conventional approaches to law in the legal discourses.

This article explores the empirical and conceptual contours of 'transnational environmental law'. Its purpose is twofold. Firstly, it seeks to map the field of transnational market mechanisms for the conservation of biodiversity. This concept is often referred to in both policy and academic literature but is rarely an abstract notion exemplified through the operation of concrete mechanisms. By introducing the context in which these markets came into being and focussing on specific mechanisms, I hope to contribute material for a more concrete discussion about the aforementioned field and to harness the growing interest in the field. Secondly, by highlighting the biases inherent in the legal conception of market mechanisms, my purpose is to draw attention to the normative aspects of transnational environmental law. An ideologyconscious analysis in the context of regulatory instruments and transnational law helps to articulate a conceptualization of transnational environmental law, where an understanding of

\footnotetext{
${ }^{14}$ E. C. Fisher, 'Unpacking the Toolbox: Or Why the Public/Private Divide Is Important In EC Environmental Law', in M. Freedland \& J.B. Auby (eds.), The Public Law/Private Law Divide: Une entente assez cordiale? (Hart Publishing, 2006), pp. 215-42.

${ }^{15}$ G. Teubner, 'Altera Pars Audiatur: Law in the Collision of Discourses', in R. Rawlings (ed.), Law, Society and Economy (Oxford University Press, 1997), pp. 149-76.
}

16 O. Perez, 'The Many Faces of the Trade-Environment Conflict: Some Lessons for the Constitutionalization Project', in C. Joerges, I.J. Sand \& G. Teubner (ed.), Transnational Governance and Constitutionalism (Hart, 2004), pp. 233-56...

17 G.P. Callies \& P. Zumbansen, Rough Consensus and Running Code: A Theory of Transnational Private Law (Hart, 2012), at p. ix; V. Heyvaert \& T.F.M. Etty, 'Introducing Transnational Environmental Law' (2012) 1(1)

Transnational Environmental Law, pp 1-11, at 2. 
normative dimensions is just as fundamental as is accounting for the multiplicity of jurisdictions and non-state actors.

This article unfolds in the following manner. Following the introduction, in the second part I outline the processes that have led to the development of a new generation of the transnational regulatory strategy for biodiversity conservation. I describe concrete cases of these mechanisms in the third part. The fourth part is devoted to the key concept of the market and its problematization in different disciplines. The conclusion suggests a different way of investigating transnational environmental law that follows on from the story of biodiversity markets: viewing markets as a misleading diversion from the existence of conflicts about epistemologies and worldviews. Thus, my appeal is to 'bring politics back' to the analysis of law in action.

\section{INCENTIVIZING BIODIVERSITY CONSERVATION}

\subsection{Pragmatism and governance trends}

Markets for biodiversity represent a response to the enduring crisis of biodiversity conservation and continuing failures to act on it. One of the reasons for their emergence is the impatience with and despair over states' policies in managing and legislating biodiversity, or - at the very least - their poor enforcement, a trend that has lasted over many decades. Even if governments' policies have in some cases been effective in reducing the rate of exploitation of land, they have largely failed to encourage the sustainable management of biodiversity over the long term. Many frame the key puzzle of biodiversity conservation as a question of how to "compensate guardian communities for forgoing opportunities from profitable exploration in order to have them conserve a resource of global benefit'. ${ }^{18}$

The creation of appropriate incentives to encourage this redistribution ('incentivization') played an important role in the discussion about the creation of market mechanisms. In closing the gap between private and public benefits, public sector funding has proven insufficient ${ }^{19}$ and other, more 'decentralized' options have been explored since the 1980s. ${ }^{20}$ But while, for some, practices such as trophy hunting, debt-relief, bioprospecting and ecotourism all represent positive examples of a new management paradigm of 'community-based conservation', others

\footnotetext{
18 T. Swanson, 'Economics of a biodiversity convention' (1992) 21(3) Ambio, pp. 250-7.

${ }^{19}$ See, e.g., R. O’Sullivan \& R. Saines, 'International Market Solutions to Protect Tropical Rainforests', in D. Freestone \& C. Streck, (eds.), Legal Aspects of Carbon Trading: Kyoto, Copenhagen, and Beyond (Oxford University Press, 2009), pp. 583-605, at 594.

${ }^{20}$ See, e.g., E. Lutz \& J. Oliver Caldecott (eds.), Decentralization and Biodiversity Conservation (World Bank, 1996); C.T. Reid, 'The Privatisation of Biodiversity? Possible New Approaches to Nature Conservation Law in the UK' (2011) 23(2) Journal of Environmental Law, pp. 203-31.
} 
contest these as a 'false conservation' and as part of an agenda that primarily serves the capital and (Western) elites. ${ }^{21}$

In the last decade, the effects of environmental change have begun to be assessed not only in terms of natural sciences but also more holistically, by examining their impacts on society and the economy. The increasing recourse to economics has been used both as additional justification for action, supplementing scientific evidence, and as a means of better communicating the implications of the environmental crisis to target groups. In the field of biodiversity conservation, the support for incentivization was further strengthened by attempts to estimate the (global) value of ecosystem services and natural capital. ${ }^{22}$ Far from being exercises of economic accounting only, these endeavours directly addressed the question of an appropriate policy response. They advanced the idea of economic and financial interventions being powerful regulatory instruments and explicitly called for the 'greater use of economic instruments and market-based approaches in the management of ecosystem services. ${ }^{23}$

More broadly, the idea of relying on markets and private funds in biodiversity governance should be linked to the prevalent governance method, which began in the West in the 1990s, of transferring regulatory power away from the state, the reduction of public expenditure and the growing responsibilities of the private sector. ${ }^{24}$ This strategy gained additional prominence in environmental law towards the end of the 1990s, due to the experience in the climate regime, where non-state actors were involved in number of mechanisms, both treaty-mandated and voluntary. ${ }^{25}$ Mounting evidence convinced the policymakers of the comparable economic justification for also scaling up biodiversity issues, and invited them to replicate relevant aspects of the climate model.

\subsection{International institutions}

The effort of finding workable incentives for conservation of biodiversity emerged in slightly different contexts in different institutions, but these diverse processes can be pooled and

\footnotetext{
${ }^{21}$ See, J. McCarthy, 'Devolution in the Woods: Community Forestry as Hybrid Neoliberalism' (2005) 37(6) Environment and Planning A, pp. 995-1014.

22 See especially R. Costanza et al., 'The Value of the World's Ecosystem Services and Natural Capital' (1997) 387(6630) Nature, pp. 253-260; UNEP, Millennium Ecosystem Assessment: Ecosystems and Human Wellbeing: Synthesis (UNEP, 2005); TEEB, The Economics of Ecosystems and Biodiversity: Mainstreaming the Economics of Nature: A Synthesis of the Approach, Conclusions and Recommendations of TEEB (2010), available at: http://www.teebweb.org/teeb-study-and-reports/main-reports/synthesis-report/.
}

23 UNEP, Millennium Ecosystem Assessment: Ecosystems and Human Well-being: Synthesis (2005), at p. 21.

${ }^{24}$ See, e.g., C. Donnelly, Delegation of Governmental Power to Private Parties: A Comparative Perspective (Oxford University Press, 2007).

25 See, e.g., K. Raustiala, 'Nonstate Actors in the Global Climate Regime', in U. Luterbacher \& D. F. Sprinz (eds.), International Relations and Global Climate Change (MIT, 2001), pp. 95-118; C. Streck, 'Innovativeness and Paralysis in International Climate Policy', (2012) 1(1) Transnational Environmental Law, pp. 137-152. 
described as one overall picture. In order to illustrate this, I will examine the development of discourses and actions for the international conservation of biodiversity as these took place in three institutional formats: the Convention on Biological Diversity (CBD), ${ }^{26}$ the United Nations Environment Programme (UNEP), and the International Union for Conservation of Nature (IUCN). These institutions play a leading role in conservation more generally and in this particular case in setting the agenda for market mechanisms. They differ starkly in their membership, institutional goals, priorities and activity, amongst other things. My aim in outlining the work of these institutions is to demonstrate that what is going on can be viewed as a single global move towards an 'incentivization' of nature.

The CBD's appetite for couching measures for conservation of biodiversity as incentives results from explicit treaty provisions ${ }^{27}$ as well as the States Parties' growing motivation to employ a more economic approach to the implementation of the treaty. There is increased recognition of the fact that built-in incentives of sustainable use and benefit sharing ${ }^{28}$ represent an insufficient motive for biodiversity conservation. Economic incentives are seen as a way of overcoming the treaty's weaknesses of very few strict obligations, absence of enforcement mechanisms, and insufficient buy-in/participation by the private sector. ${ }^{29} \mathrm{~A}$ further motive for development of incentives is that they overcome the scarcity of financial resources awarded by the principal financing mechanism of the treaty, the Global Environmental Facility, in the form of grants to developing states. ${ }^{30}$ Developed states have been continuously demanding that the financial mechanism should be more performance-based, thus closer to a trade exchange rather than aid flows. 31

UNEP's work on economic incentives can be placed in the context of its broader mandate of assisting particularly developing and transition countries through the improvement of their national laws. In all its work and especially during the nineties, UNEP actively promoted the

\footnotetext{
${ }^{26}$ Rio de Janeiro (Brazil), 5 June 1992, in force 29 Dec. 1993, available at: http://www.cbd.int/convention/text. Although technically a treaty, I refer to the CBD regime as an institution, based on the specific role played by Conferences of Parties; see J. Brunnée, 'COPing with Consent: Law-Making Under Multilateral Environmental Agreements,' (2004) 15(1) Leiden Journal of International Law, pp. 1-52; R. Lefeber, 'Creative Legal Engineering,' (2000) 13(1) Leiden Journal of International Law, pp 1-9.

27 CBD Article 11.

28 Sustainable use of components of biodiversity and "the fair and equitable sharing of the benefits arising out of the utilization of genetic resources" are two of objectives of the CBD; Art 1.

${ }^{29}$ See, e.g., UNEP/CBD/COP/3/18; UNEP/CBD/COP/5/15 (the programme of work on incentives, adopted in 2000); UNEP/CBD/COP/6/16.

30 S. Menzel, 'Financial Support for Biodiversity Protection in Developing Countries-Does the CBD Mechanism Lead to an Appropriate Level of Biodiversity Protection?' in R. Buse et al. (eds.), Valuation and Conservation of Biodiversity - Interdisciplinary View on the Convention on Biological Diversity (Springer, 2005), pp. 23-41.

31 See, e.g., I. Kaul, I. Grunberg \& M. A. Stern, 'Introduction', in I. Kaul, I. Grunberg \& M. A. Stern (eds.), Global Public Goods: International Cooperation in the $21^{\text {st }}$ Century (OUP, 1999) (identifying the 'Incentive gap' or the focus on aid mechanisms as part of three key obstacles to a better supply of global public goods).
} 
use of economic incentives in its portfolio of policies. ${ }^{32}$ The extension of incentives into the field of international biodiversity management thus seems a continuation of its work in national contexts. UNEP endorses market mechanisms as efficient, cost-effective and innovative. ${ }^{33}$ Equally important part of their appeal - especially from the perspective of this continually underfunded institution - are the prospects of these mechanisms generating funds for conservation. Support for the economic approach to environmental policy has culminated in UNEP's launch of the 'green economy' concept in 2009/2010, which essentially aims to reframe the global economy from a carbon intensive 'brown economy' towards a more sustainable one, based on the market-based solutions. ${ }^{34}$

The IUCN's support for incentivization is expressed through a variety of methods and institutional programmes. Since the nineties, the IUCN has supported work on economic policies through one of its six expert Commissions. Around 2002, the organization began to systematically develop close contacts with businesses, ${ }^{35}$ most of which were very responsive to its advances. ${ }^{36}$ A few years later, the IUCN started to elaborate on the idea of payment for ecosystem services, also in the international context. Much of this work has been done in the cooperation with UNEP and the CBD Secretariat. In the run up for Rio+20, the IUCN subscribed to the concept of 'green economy', aiming at integrating the value of nature into economic policy and practice, and at benefitting from the private sector leadership and innovation. ${ }^{37}$

The institutional and substantive context in which the idea for market mechanisms for biodiversity conservation has evolved, shows that these new regulatory tools have attempted to respond to a set of interrelated expectations. They seek to represent incentives that encourage the action of stakeholders, as opposed to limiting it by coercive and prescriptive obligations, and they aim to achieve integration of biodiversity into existing economic structures, rather than oppose them. Accordingly, market mechanisms do not actually present new facts, but 'speak the right language', which is used by the stakeholders - the language of the market. They

32 Critical for that was the establishment of Working Group on Economic Instrument in Environmental Policymaking in June 2001, which operates within the Economics and Trade Branch within UNEP.

33 UNEP, Economic Instruments in Biodiversity-related Multilateral Environmental Agreements (2004).

34 UNEP, Towards a Green Economy: Pathways to Sustainable Development and Poverty Eradication (2011); see also the final resolution of Rio+20, The Future We Want, UN Doc. A/66/L.56, available at: http://www.uncsd2012.org/rio20/thefuturewewant.html. See also Morrow, n. 2 above; J. Penca, 'Green economy and environmental law: a mismatch and why bother?' in V. Sancin (ed.) International Environmental Law: Contemporary Concerns and challenges (GV Založba, 2012).

35 Business and Biodiversity Programme is a specific unit of the Secretariat, focusing specifically on influencing private sector policy and practice.

${ }^{36}$ K. I. MacDonald, 'The Devil Is in the (Bio)Diversity: Private Sector 'Engagement' and the Restructuring of Biodiversity Conservation,' (2010) 42(3) Antipode, pp. 513-50, at pp. 537-8.

${ }^{37}$ IUCN, Position Paper on Green Economy (2012), available at: https://cmsdata.iucn.org/downloads/position_paper_on_green_economy_22march2012.pdf 
also tap into new sources of funding. Finally, they provide a means of integration of the private sector into the regime alongside states.

The assumption embedded within the incentivization approach is that the fundamental problem for the degradation of biodiversity lies in the fact that the full value of nature is not recognized by the economic accounts with which we operate. ${ }^{38}$ The rhetoric of the need for internalization of externalities has been diffused among businesses, governments, and NGOs as a platform needed to conserve biodiversity. ${ }^{39}$ The notions of '(restoring) natural capital', 'ecological infrastructure' and '(payments for) ecosystem services' are some of the building blocks of a new lexicon, ${ }^{40}$ transforming conservation from a risk or liability to a 'potential profit centre'. ${ }^{41}$ Changing the reference of the discourse about the conservation of nature from one about values, rights and duties to one of an economic imperative raises controversy. Some perceive it as an 'opportunity for making biodiversity conservation 'a viable business proposition in its own right' 42 while others lament it for 'fit[ting] perfectly with the possibilities for maximising the earnings generated by obligatory consumption.' 43

The economic repackaging of the biodiversity project has found its way deep into the institutional structures and the central themes of work by conservation organizations, including large transnational non-governmental organizations (NGOs). Some of those that today have a programme or section devoted to market mechanisms, 'green economy' or business

\footnotetext{
38 J. Metcalfe \& F. Vorhies, 'Exploring the case for a green development mechanism', International Workshop on Innovative Financial Mechanisms: First meeting, Bonn, 27-29 January 2010, available at: http://www.cbd.int/financial/doc/gdm-exploring-the-case-en.pdf.

${ }^{39}$ D. Jarrett, 'Biodiversity, Ecosystem Services and Natural Capital: Terms Matter' (2012), available at: http://ecometrica.com/blog/biodiversity-ecosystem-services-and-natural-capital-terms-matter/
}

${ }^{40}$ E.g. TEEB - The Economics of Ecosystems and Biodiversity for National and International Policy Makers (2009), Chapter 9.

41 J. Bishop et al., Building Biodiversity Business (Shell International and IUCN, 2008), at p. 11.

${ }^{42}$ Ibid., at p. 10.

${ }^{43}$ Grain, 'No air, don't sell yourself' (April 2005) Seedling, pp. 34-41, available at: http://www.grain.org/article/archive/categories/34-seedling-april-2005. 
involvement are the World Wildlife Fund (WWF), ${ }^{44}$ Conservation International (CI), ${ }^{45}$ the World Resources Institute 46 and the Nature Conservancy. ${ }^{47}$

The discourses about incentives and market mechanisms represent both a project that has come into being with the active engagement of the major agenda-setting institutions and a consensus that now exists between them; this collective development is taking place across these institutions simultaneously. Only a few NGOs, associated with a more grassroots movement, usually located in the global South, are opposed to the movement. ${ }^{48}$

The purpose of the overview of ideational embedding and expectations of market mechanisms goes beyond that of setting the scene. Contextual developments help to reveal that a whole new way of thinking about the biodiversity problem had been induced. I claim that discourses, both in their institutional and substantive dimensions, act not only as precursors to the regulatory tools of market mechanisms, but as an integral part of law and regulation. If we understand environmental governance not only as a rational process of instrumental character and analytical effort, but also as a social and political phenomenon, we must recognize that the choice of how to frame the biodiversity problem influences policy outcomes. ${ }^{49}$ Contouring the biodiversity problem as insufficient integration in the dominant political economy, based on the market and governance structures, which are heavily influenced by the private actors, means that the solutions have to be sought within the same framework.

The discourse of incentivization furthers a belief that biodiversity loss and conflicts related to the use of biodiversity may be resolved if only we can access more financial resources and if markets can extend far enough to include areas of biodiversity and ecosystem services. This proposition directly contrasts with the claim that a lack of funding for biodiversity is a matter of distribution of government funds rather than insufficiency, as environmentally harmful

\footnotetext{
${ }^{44}$ WWF builds strong relationships with businesses especially through the initiatives Strategic partnerships and Transforming markets; available at http://www.wwf.org.uk/what_we_do/working_with_business/how_we_work_with_business/

${ }^{45} \mathrm{CI}$ pioneers in the use of 'conservation incentive agreements' as a key mechanism for 'strategies that make conservation economically viable'; available at

http://www.conservation.org/learn/culture/communities/Pages/incentives.aspx

46 'Markets \& enterprise' is one of four programme areas of WRI; available at http://www.wri.org/markets

${ }^{47}$ Pursuing ' non-confrontational, pragmatic, market-based solutions to conservation challenges' is the very rationale of the Nature Conservancy; available at http://www.nature.org/about-us/our-partners/index.htm.

${ }^{48}$ E.g. the signatures of: Acción Ecológica, Carta abierta a la secretaría de la Convención de diversidad biológica y a los gobiernos de Japón, India, Noruega, Suecia y Ecuador, available at:

http://www.accionecologica.org/component/content/article/1543-carta-abierta-a-la-secretaria-de-la-convencionde-diversidad-biologica-y-a-los-gobiernos-de-japon-india-noruega-suecia-y-ecuador.

${ }^{49}$ A. Tversky \& D. Kahneman, 'The Framing of Decisions and the Psychology of Choice' (1981) 211 Science, pp. 453; M. Hajer, The Politics of Environmental Discourse: Ecological Modernization and the Policy Process (Clarendon Press, 1995).
} 
subsidies today more than outweigh the funding available for biodiversity conservation. 50 This construction of the biodiversity problem silences many other demands expounded through the debates about biodiversity. The most salient among these are calls for the recognition and reparation of colonial injustices, for a social and political autonomy, territory, identity and a reformed economy. ${ }^{51}$

\section{TRANSNATIONAL MARKET MECHANISMS FOR BIODIVERSITY}

Markets for biodiversity, even those operating within national jurisdictions, (wetland offsets or mitigation banks, fishing quotas etc.) are a relatively recent development but are currently undergoing swift evolution. A report on the state of the art listed that, in 2011, 49 markets were in place around the world, and that an additional 27 were in progress to full development. ${ }^{52}$ This signifies a rapid increase in programmes from the previous year. ${ }^{53}$ The same report estimates that the value of these markets is at least 2.4-4.0 billion United States (US) dollars annually. It also indicates that the leader among the regions hosting these markets is North America with the US and Canada, followed by Australia, while the European Union is only beginning to tap into them. Participation in the global South is mostly limited to those countries with emerging economies (Malaysia, Indonesia, Brazil, South Africa), while least developed countries in the tropical zones are almost entirely excluded.

While more recent, the transnational level is also accommodating the implementation of biodiversity markets. Transnational market mechanisms are inspired by national models, but they cross the borders of individual states. Three concrete cases of transnational market mechanisms that I will briefly describe below (the Business and Biodiversity Offsets Programme (BBOP), the Green Development Mechanism (GDM), and Reduced Emissions from Deforestation and Forest Degradation (REDD)) typify many of the features of the regulatory innovations that have been advocated.

\footnotetext{
50 A. James, K. J. Gaston \& A. Balmford, 'Can We Afford to Conserve Biodiversity?' (2001) 51(1) BioScience, pp. 43-52.

51 See, e.g., A. Escobar, 'Whose Knowledge, Whose Nature? Biodiversity, Conservation, and the Political Ecology of Social Movements,' (1998) 5(1) Journal of Political Ecology, pp. 53-82.

52 Madsen et al., n. 11 above.

53 In 2010 there were 39 markets and 25 under development; ibid.
} 


\subsection{Business and Biodiversity Offsets Programme}

The BBOP implements the model of so-called conservation banking born initially in the US in the 1990s. ${ }^{54}$ It rests on the idea that project developers who are causing damage to habitats or species in the process of their economic activity should (make a commitment to) compensate by restoring an ecological value comparable to that which has been altered.

The BBOP is a network of partners: conservation organizations, corporations, finance companies and government bodies. It enjoys wide participation: its advisory board has over 50 members and its 'learning network' over 500 members. These numbers attest to the BBOP's ambition to become a visible player on the biodiversity markets. Although not carrying out actual projects, the BBOP aims to influence the markets of biodiversity offsets by offering coherent guidance for project implementation, including indicators for the evaluation of individual projects. 55

One of the BBOP's central tenets is the principle of 'mitigation hierarchy', which seeks to ensure that all the possible mitigation measures are taken to avoid and minimize negative impacts as far as possible and marks biodiversity offsets as a last resort option for developers. But to many, the offsetting schemes are a more permissive alternative to an outright ban on damaging activities, granting the 'licence to destroy', which' could used to justify avoidable destruction'. ${ }^{56}$ The scheme claims to be neutral in that it 'puts a cost on [an endangered species or habitat] for those who would harm it, and at the same time it creates a value for those who would conserve it. ${ }^{57}$ But in practice offsetting works for the developer, as it is applied only to projects above a certain threshold, it follows rather than precedes the destruction and brings positive results only in very limited (ecological) circumstances. 58

54 Wheeler, D. P. \& J. M. Strock, Official policy on conservation banks (1995), available at: http://ceres.ca.gov/wetlands/policies/mitbank.html.

55 Business and Biodiversity Offsets Programme, Standard on Biodiversity Offsets (2012), available at: http://www.forest-trends.org/documents/files/doc_3078.pdf.

${ }^{56}$ G. Monbiot, The Unsung World, 8 Dec. 2012, available at http://www.monbiot.com/2012/12/08/the-unsungworld/.

57 R. Bayon, 'Biodiversity Banking: A Primer', in Worldwatch Institute, 2008 State of the World: Innovations for a Sustainable Economy (2009), pp. 123-37, at p. 126, available at: http://www.ecosystemmarketplace.com/media/pdf/SOW08-9-Bayon.pdf.

58 P. Gibbons, A Tree for a Tree:Can Biodiveristy Offsets Balance Destruction and Restoration? (The Conversation, 2011), available at: http://theconversation.com/a-tree-for-a-tree-can-biodiversity-offsets-balancedestruction-and-restoration-3682 


\subsection{The Green Development Mechanism}

The idea of the GDM emerges from the better-known Clean Development Mechanism (CDM) ${ }^{59}$ of the climate change regime. Rather than carbon emissions, the 'trading element' in this mechanism is a component of biodiversity or an ecosystem service. Although the CDM has been beset with controversies since the very beginning, 60 it has nonetheless inspired the biodiversity community. In 2006, UNEP and IUCN in cooperation with the Secretariat of the CBD, began looking into the options for an 'international payments for ecosystem services' mechanism with a special emphasis on biodiversity and a broad range of ecosystem services. ${ }^{61}$ In doing so, the Green Development Initiative (GDI) asserted itself as a coordinator of the GDM, operating from 2009. The GDI aimed at raising sufficient interest and support for the launch of the GDM at the $10^{\text {th }}$ Conference of Parties (COP) of the CBD in 2010, but it failed to secure consensus.

The GDM was envisaged primarily as a tool that would fill the biodiversity financing gap, since public funds have been unable to do so. ${ }^{62}$ It rests on the idea that any area with some biodiversity value (a coral reef, a forest, a wetland or organic farm) may draw up a ten-year development plan, which is certified, registered and then put onto the market to be bought by companies or others interested in biodiversity 'credits'.63 The GDI's main efforts are thus focused on establishing a standard and a registry that will support a certification process for biodiversityresponsible land management.

In advancing the idea of the GDM, the GDI is keen to maintain close links with the CBD and to present the GDM as a 'spin-off instrument' of this intergovernmental forum. The GDI purports to respond directly to the invitation by the CBD COP in 2008 to 'come forward with new and innovative financing mechanisms' and to the strategic decision for 'enhancing the engagement of the business community'. ${ }^{64}$ The GDI further explains that it seeks to contribute

\footnotetext{
${ }^{59}$ Kyoto Protocol to the United Nations Framework Convention on Climate Change, Kyoto (Japan), 10 Dec. 1997, in force 16 Feb. 2005. Available at: http://unfccc.int/kyoto_protocol/items/2830.php; Art 12. ${ }^{60}$ E.g. A. Vlachou \& C. Konstantinidis, 'Climate Change: The Political Economy of Kyoto Flexible Mechanisms' (2010) 42(1) Review of Radical Political Economics, pp. 32-49; J. Cabello, 'The Politics of the Clean Development Mechanism: Hiding Capitalism Under the Green Rug', in S. Böhm \& S. Dabhi, n. 10 above; C. Voigt, 'Is the Clean Development Mechanism Sustainable - Some Critical Aspects' (2008) 15 Sustainable Development Law \& Policy, pp 15-21.

${ }^{61}$ See decisions UNEP/CBD/VIII/26, para 6 (c); UNEP/CBD/VI/15 Annex, para 37; UNEP/CBD/VIII/13, para 4.

62 J. Metcalfe \& F. Vorhies, n. 38 above.

63 GDI, BioAreas Reference Guide: The BioAreas Standard \& Registry for Biodiversity-Responsible Area Management (2012), available at: http://gdi.earthmind.net/files/BioAreas-Reference-Guide-Version101Mar2012.pdf.

${ }^{64} \mathrm{Ibid}$, at pp. 16 - 18; the decision being referred to is UNEP/CBD/COP/9/IX, Part B, para 4.
} 
to the CBD's objectives and also to the implementation of the most recent Strategic Plan for Biodiversity 2011-2020.65

Those wary of the GDM demand that at least strong safeguards need to be put in place before any such mechanisms are developed. ${ }^{66}$ Concerns are raised that the enthusiasm for projects may bypass existing land rights and the needs of native communities, indigenous peoples and other minority groups. ${ }^{67}$ Despite the proponents' assurances that the purpose of the scheme is precisely to empower these peoples with resources so that they can continue to be the guardians of landscapes, 68 the requisite of drawing a management plan for its subsequent authorization resembles a top-down attitude rather than one in which communities determine the meaning of 'sustainability' themselves.

\subsection{Reduced Emissions from Deforestation and Forest Degradation}

Reduced Emissions from Deforestation and Forest Degradation (REDD) ${ }^{69}$ is a form of market for conservation whereby actors in developed countries provide direct payments to developing countries in exchange for their commitment to preserve the benefits of forests. REDD is presented as an unprecedented opportunity for forests, capable of overcoming persistently failed attempts at a forestry regime and of becoming the most successful large-scale source of funding for forests. ${ }^{70}$ It is also seen as a way of advancing biodiversity concerns into the climate regime, an avenue which has established a dominating role in the environmental agenda. ${ }^{71}$

The idea for REDD was born within the United Nations Framework Convention on Climate Change (UNFCCC), 72 in 2005, but negotiations on its legal form within this forum are still ongoing. However, the slow pace of the UNFCCC talks in recent years has not forestalled developments in parallel avenues, mainly operated by transnational coalitions of individual

\footnotetext{
65 GDI, Biodiversity Tools for the GDI Objectives, available at: http://gdi.earthmind.net/toolkit/biodiversity/.

${ }^{66}$ H. Paul \& A. Lorch, 'Finance, targets, green economy and innovative financial mechanisms' (2010) 5 Square Brackets, pp 6-7.
}

${ }^{67}$ S. Leahy, 'Environment: Market-based Conservation Brewing in Nairobi' (Inter Press Service, 1.6.2010;) available at: http://www.ipsnews.net/2010/06/environment-market-based-conservation-brewing-in-nairobi/. 68 Ibid.

${ }^{69}$ I use the term REDD to refer to the full scope of activities, covered also by 'REDD-plus', i.e. including those supporting the conservation of forests, their sustainable management and the enhancement of forest carbon stock.

70 See International Forestry Review - Special Issue on REDD (2008) 10(3); A. Angelsen et. al. (eds.), Analysing REDD+: Challenges and choices (CIFOR, 2012).

$71 \mathrm{UNEP} / \mathrm{CBD} / \mathrm{SBSTTA} / \mathrm{XIII} / 6$, para 22.

72 Rio de Janeiro (Brazil), 4 June 1992, in force 21 Mar. 1994, available at: http://unfccc.int/key_documents/the_convention/items/2853.php. 
experts, governments, corporations, and NGOs. The projects are at diverse stages of advancement and are run in different shapes, including their funding arrangements, but mostly within the framework of multilateral initiatives. ${ }^{73}$

Efforts to secure a credible future for the REDD scheme have failed to rebut harsh critiques of its founding idea and implementation. ${ }^{74}$ Seemingly technical issues in the complex negotiations about REDD, such as the definition of 'forests', 'reference levels', and 'leakage' translate into conflicting views between actors. The views are fundamentally related to their conceptions of justice, particular situations of countries and the benefits they might draw from the mechanism.

Another contested issue are property rights for forest carbon, an abstract and new legal idea. At the source of its controversy is the question of who actually holds them: forest dependent peoples, forest communities, individuals, governments or corporations, if anyone at all. Carbon rights are inherently contingent on the issues of land rights and tenure, which remain unresolved in many developing countries, negatively affecting particularly vulnerable groups. ${ }^{75}$ They are related to technical and governance capacities of forest communities and states. Not infrequently, the aim of carbon reduction in forests is in direct competition with the objectives of food security and environmental integrity: as the REDD prioritizes the forests storing the highest amount of carbon, the problem of deforestation may only be shifted onto other forests, possibly with more biodiversity. Currently, the only assurance for the positive impact of REDD projects on biodiversity are claims of compliance with voluntary standards. ${ }^{76}$

Negotiations over the design and implementation of REDD and its promises may obscure the fact that activities now framed in terms of REDD had been pursued for years, without however being accounted for in terms of carbon dioxide $\left(\mathrm{CO}_{2}\right)$ emissions reductions. Or, despite being squared within measurable and verifiable criteria and standards, the debates about REDD, in fact, concern a number of issues of sustainable development and equity, underlying the traditionally controversial forest politics. ${ }^{77}$

\footnotetext{
${ }^{73}$ See, e.g., Forest Carbon Partnership Facility of the World Bank, available at: http://www.forestcarbonpartnership.org/; UN REDD Programme, available at: http://www.un-redd.org/; the REDD+ Partnership, available at: http://reddpluspartnership.org/en/.

${ }_{74}$ See, e.g., Friends of the Earth, Dangerous Distraction, Why Offsetting is Failing the Climate and the People: The Evidence (2009), available at: http://www.foe.co.uk/resource/briefing notes/dangerous distraction.pdf; Durban Group for Climate Justice, Durban Statement on REDD (2010), available at: http://www.durbanclimatejustice.org/wp-content/uploads/2010/04/durbanREDDstatement_en.pdf; Chris Lang, Interview with Teguh Surya, WALHI: “We are against REDD. We are against carbon trading. " (2012), available at: http://www.redd-monitor.org/2012/03/09/interview-with-teguh-surya-walhi-we-are-against-reddwe-are-against-carbon-trading/.
}

${ }^{75}$ G. Wright, 'Indigenous People and Customary Land Ownership Under Domestic REDD Frameworks: A Case Study of Indonesia' (2012) 7(2) Law, Environment and Development Journal, pp 119-31.

76 C. A. Harvey et al., What is Needed to Make REDD+ Work on the Ground? Lessons Learned From Pilot Forest Carbon Initiatives (Conservation International, 2010), at p. 54..

77 See, e.g., D. Humphreys, Forest Politics: The Evolution of International Cooperation (Earthscan, 1996); D. Humphreys, Logjam: Deforestation and the Crisis of Global Governance (Earthscan, 2006). 


\subsection{Overview of transnational market mechanisms for biodiversity conservation}

In their design, the BBOP, the GDM and REDD are not without links to traditional interstate structures (CBD and UNFCCC) and are built on models and experience from domestic legal systems. Having formed independent institutional structures, these mechanisms nevertheless like to trace their origin to international fora and seek to retain institutional cooperation with them as a way of demonstrating their legitimacy.

Market mechanisms for biodiversity are the result of a multi-actor and multi-jurisdictional collaboration, rather than an undertaking by a single actor. Prominent actors involve intergovernmental organizations, large conservation organizations, governments, sub-state bodies (ministries or specialized agencies) and individuals in their role as experts.

The commitment by major actors to the idea of market mechanisms is met with, if hardly balanced by, opposition coming typically from smaller NGOs and individuals. Apart from the disapproving the 'risks, the speed and uncritical enthusiasm' for the market mechanisms, i.e. their operationalization, ${ }^{78}$ they disagree with the general ideology that promotes the use of market mechanisms. ${ }^{79}$ They contend that these mechanisms:

seek control over land, forests, water and biodiversity as means to compensate for the loss of biodiversity or as raw materials for new technologies. They extol the paradigm that the solution lies in the market, in property rights, in the proper assignment of prices and the commodification of all of nature, traditional knowledge and cultures associated with it, to the detriment of justice, sovereignty and respect for human rights and the rights of nature. ${ }^{80}$

Opposition towards market mechanisms is directed towards the perception that these mechanisms are legitimizing certain values (privatization, new technologies), principles (property rights) and worldviews (commodification) while effectively eroding others (justice, sovereignty, rights), which were previously also accommodated within the legal discourse.

Transnational market mechanisms are legally applicable only between the contracting parties, but these agreements spread a paradigm, to which many may be opposed. These controversial structures may not have been formally endorsed by the intergovernmental decisions, they may be a voluntary arrangement or still be in an experimental period, but transnational coalitions strike deals that enable mechanisms to operate and generate increasingly sophisticated rules that shape the likely future design of regulatory tools. Even though individual deals are negotiated, the very existence of market mechanisms is not.

\footnotetext{
${ }^{78}$ K. H. Redfort \& W. W. Adams, 'Payment for Ecosystem Services and the Challenge of Saving Nature' (2009) 23(4) Conservation Biology, pp. 785-7.

${ }^{79}$ See, e.g., Acción Ecológica, n. 48 above.

80 Acción Ecológica, n 48 above.
} 
Moreover, market mechanisms present some straightforward challenges to positive law. For instance, they implement a wholly new approach in relation to the responsibility to pay and the distribution of benefits arising out of environmental protection. The 'polluter-pays' principle, one of the core principles of environmental law, is effectively being substituted by the conceptually contrasting principle of 'beneficiary-pays', fundamentally changing the nature of the flow of benefits and the perception of responsibility. ${ }^{81}$ Continual claims of the implementation of objectives of international law by the institutions running market mechanisms may obscure substantive deviations from the principles established in international environmental law. Eager to see some activity, States seem to mind neither a competing form of rule-making by transnational networks nor the substantive challenges to established norms.

\section{THE CENTRAL THEME OF MARKETS}

Many of the transnational market mechanisms for biodiversity operate on a contractual basis and can be classified as 'transnational conservation contracts'. ${ }^{82}$ Equally, they can be tagged as 'innovative' 83 or 'flexible' 84 mechanisms, implying that they lie outside the structures of traditionally prescriptive regulation and inter-state relationships, and that they can thus be analytically dismissed as a 'sui generis' category. Nevertheless, I insist on conceptualizing them as 'market mechanisms'. This is not only a term used by many stakeholders in the discourse. The emphasis on 'markets' appropriately highlights several particular substantive patterns of transnational law that have been suppressed in the legal analyses of developments in conservation governance, as well as the new generation of legal tools which are hoped to increase the implementation of international commitments. The next three sections examine the meaning of 'markets' in actual biodiversity markets and economics, the regulatory choice debate in environmental law, and in studies of neoliberalism. The focus is on discovering the concerns and conflicts embedded within or concealed by the use of the term 'markets'.

\subsection{Biodiversity markets and 'true' markets}

Although the processes described above revolve heavily around markets both conceptually and semantically, this central concept is rarely specified and dealt with. Claims that biodiversity markets are 'hard to define, fragmented, swiftly changing, and opaque' are unhelpful in a

\footnotetext{
${ }^{81}$ D. A. Farber, 'Adapting to Climate Change: Who Should Pay' (2007) 23 (1) Journal of Land Use and Environmental Law, pp. 1-37, at pp. 26-8.

82 N. Affolder, 'Transnational Conservation Contracts' (2012) 25(2) Leiden Journal of International Law, pp. 443-60.

${ }^{83} \mathrm{UNEP} / \mathrm{CBD} / \mathrm{WS}-\mathrm{IFM} / 1 / 1$

${ }^{84} \mathrm{OECD}$, Paying for Biodiversity: Enhancing the cost-effectiveness of payments for ecosystem services, available at: http://www.oecd.org/env/resources/46135424.pdf
} 
framework that sets out to describe them. ${ }^{85}$ It is staggering that so little clarity and precision is poured into the terminology that underlies this regulatory framework.

In one of the rare attempts to introduce precision, 'market based instruments for biodiversity' are described as 'incentive systems that operate through establishing prices for environmental services, via a market. The markets in question are either established ones ... [or] "created", usually with some form of encouragement from government - as in the case of habitat banking.' ${ }^{86}$ In the policy literature, 'market mechanisms', 'market-based instruments', 'economic incentives', and 'economic instruments' are all used to describe an alternative to direct regulation.

Behind these labels, however, different types of markets are represented. The instruments that are categorized as market mechanisms in policy and the academic literature include tradable permits or biodiversity offsets, conservation easements, payments for ecosystem services, subsidies, taxes, charges and fees, eco-labelling schemes, performance bonds, deposit and refund schemes, liability and compensation funds, and financial mechanisms. ${ }^{87}$ Many different dividing lines could be used to classify these categories. The type of currency traded may vary from a habitat or species to an ecosystem service, a scheme could be voluntary or mandated by a regulatory requirement, its scale local or global, the role of the state in establishing and supporting the scheme could be weak or strong, and types of (dominant) actors may differ from NGOs, communities and businesses.

The literature on 'market mechanisms' in biodiversity speaks about arrangements that are based on very different theoretical underpinnings. Using the same tag for diverse programmes and products makes little sense from the point of view of economic theory. ${ }^{88}$ Reliance on 'markets' corresponds to a generic understanding of markets in economics as 'mechanism[s] through which buyers and sellers interact to set prices and exchange goods and services'. ${ }^{89}$ But present biodiversity markets almost invariably fail to comply with the notion of a competitive market, which is determined by the existence of a sufficiently large number of buyers and sellers who cannot influence the price of the good or service. ${ }^{90}$ Thus, instead of truly competitive transactions, the current deals are much better described as negotiated agreements between

\footnotetext{
85 Madsen, n. 11 above, at p. vii.

${ }^{86}$ Etec, IEEP et.al, The use of market-based instruments for biodiversity protection-The case of habitat banking - Technical Report (2010), available at: http://ec.europa.eu/environment/enveco/pdf/eftec_habitat_technical_report.pdf.

${ }^{87}$ See, e.g., OECD, Handbook of Market Creation for Biodiversity: Issues in Implementation (2004); OECD, n. 11 above, I. Bräuer et al., The Use of Market Incentives to Preserve Biodiversity (2006), available at: http://ec.europa.eu/environment/enveco/biodiversity/pdf/mbi.pdf.

${ }^{88}$ E. Broughton \& R. Pirard, What's in a name? Market-based instruments for biodiversity (IDDRI, 2011).

${ }^{89}$ P. A. Samuelson \& W. D. Nordhaus, Economics, $17^{\text {th }}$ ed. (McGraw Hill, 2001), at p. 27.

90 P. Krugman \& R. Wells, Economics, 2nd ed. (Word Publishers, 2009), at p. 62.
} 
ecosystem service providers and users. ${ }^{91}$ Schemes with a single buyer - e.g. a government, water company, electricity producer, or tourism operator - are frequent. ${ }^{92}$

What all of the 'biodiversity market' arrangements do seem to share is a price component ${ }^{93}$ or a payment that is used for the protection, restoration, or management of biodiversity. ${ }^{94}$ For this to take place, some sort of economic valuation is inevitably involved.

The usage of the term 'market mechanisms' is therefore a convention rather than a reflection of any specific and comprehensive determining features beyond price or payment. Current biodiversity markets are sustained by a belief in the markets and the confidence that they are likely to operate according to the rules of markets in the future, rather than functioning in such ways in the present. ${ }^{95}$ Conditions for the operation of competitive markets in existing biodiversity market mechanisms are still far away. They would involve setting up more precise legislative frameworks, improving processes of monitoring, reporting and verification, and not least also safeguards to ensure environmental integrity and just outcomes for those involved.

At this stage, 'biodiversity markets' may be said to refer to any process, including discursive practice, which employs the principles of economics to appeal for action. When viewed in this sense, 'biodiversity markets' build on the ability of economic instruments to communicate clearly the impacts of biodiversity degradation and create a sense of urgency. In so doing, they have diversified the vocabulary as the means of persuasion of stakeholders and have formed a new instrumental-value register in biodiversity governance, ostensibly more influential for the broader public, politicians and business-leaders than the purely ethical-political articulations. ${ }^{96}$

\subsection{Market mechanisms in regulatory choice scholarship}

'Market mechanisms' are an established category in the debate about regulatory instruments in environmental law. ${ }^{97}$ Here too, the literature refers to an extremely heterogeneous group under

\footnotetext{
${ }^{91}$ S. Wunder \& M. T. Vargas, Beyond Markets: Why Terminology Matters (The Ecosystem Marketplace, 2005), available at:

http://www.ecosystemmarketplace.com/pages/dynamic/article.page.php?page_id=1252\&section=water_market \&eod $=1$.

92 S. Wunder, 'Are Direct Payments for Environmental Services Spelling Doom for Sustainable Forest Management in the Tropics?' 2006 11(2) Ecology and Society, pp. 23-34.

93 Broughton \& Pirard, n. 88 above, at p. 4.

94 Madsen, n. 11 above, at p. 1.

95 Broughton \& Pirard, n. 88 above, at p. 14.

${ }^{96}$ G. Daily, Preface, in G. Daily (ed.), Nature's Services: Societal Dependence on Natural Ecosystems (Island Press, 1997), at pp. Xv-Xx.

${ }^{97}$ D. Driesen, 'Alternatives to Regulation? Market Mechanisms and the Environment,' in M. Cave, R. Baldwin \& M. Lodge The Oxford Handbook of Regulation (Oxford University Press, 2010), pp. 203-22.
} 
the same label. The underlying logic of economic incentives lies in the fact that it uses markets and market signals, rather than government intervention through explicit directives, to oblige actors to reach the set targets or achieve the desired behaviour. ${ }^{98}$ Implicitly, the category of market mechanisms represents an alternative to both public payments and prescriptive regulation, and is also a synonym for 'altering development paths' ${ }^{99}$ Frequently, the distinction between economic incentives and prescriptive regulation is difficult to expound without the opposition to its counterpart. At other times it is misrepresented as being more straightforward than it actually is. In fact, many instruments are 'hybrids', as many create markets while at the same time involving some kind of government intervention. 100

Despite the unclear boundary, there is an on-going debate about each approach's respective advantages and disadvantages. ${ }^{101}$ Mainstream regulation scholarship still positions market mechanisms within an array of regulatory instruments that may be deployed when performing 'regulatory choice' for a particular environmental problem. 'Regulatory' or 'instrument choice', in the way I use it, refers to an analytical framework for thinking about the ways of improving the operation or efficacy of law, by choosing among instruments which range from prescriptive regulation to market mechanisms, 'flexible' or 'information-based' instruments and their hybrids. It debates relative and absolute merits and demerits of particular instruments in terms of objective and verifiable criteria (such as cost-effectiveness, distributional criteria and the technological innovation), ${ }^{102}$ but suppresses questions of values, principles and beliefs.

Shadowing the approach by the regulatory choice scholarship, the task of a policymaker or lawyer becomes a search for the most optimal instrument to fit the puzzle - a job that can be likened to one of craftsmanship. Among the problematic aspects of this approach is that it accelerates the perception of law as a toolbox, full of straightforward, purely instrumental tools and capable of 'fixing' environmental problems through better design, rather than by confronting their underlying socio-legal and ideological dimensions. ${ }^{103}$

\footnotetext{
98 R. Stavins, 'Moving to markets in environmental regulation: Lessons from twenty years of experience', in J. Freeman \& C. D. Kolstad (eds.) Moving to Markets in Environmental Regulation: Lessons from Twenty Years of Experience (Oxford University Press, 2006), pp 19-37, at p. 19.

99 Wunder, n. 92 above.

100 J. Freeman \& D. Farber, 'Modular Environmental Regulation' (2005) 54(4) Duke Law Journal, pp. 795-912, at p. 6; D. M. Driesen, 'Is Emissions Trading an Economic Incentive Program? Replacing the Command and Control / Economic Incentive Dichotomy’ (1998) 55 Washington and Lee Law Review, pp 289-350, at p. 300.
}

101 See, e.g., J. Freeman \& C. D. Kolstad, 'Prescriptive Environmental Regulations Versus Market-Based Incentives,' in Freeman and Kolstad, n. 98 above.

102 See, e.g., R. L. Revesz \& R. N. Stavins, 'Environmental law and policy', in A. M. Polinsky \& S. Shavell (eds.), The Handbook of Law and Economics (Elsevier, 2007), pp. 499-571.

103 Fisher, n. 14 above. 
The presumption toward using market mechanisms ${ }^{104}$ has been sustained by the construction of 'new' and 'better regulation'. ${ }^{105}$ Endorsement of market mechanisms is much more frequent than their problematization, despite a number of complexities and controversies involved in their transplantation to ever new jurisdictions ${ }^{106}$ and new thematic areas. ${ }^{107}$ Trading habitats or species, rather than air or water pollutants, has many specificities, which have been overlooked. ${ }^{108}$ Linking the advancement of market-based instruments to the ideology of neoliberalism is a particularly exotic scholarly venture. ${ }^{109}$

The regulatory choice debate represents only one of the possible ways of discussing the question of how to improve environmental governance. The focus on functional claims provides a distraction from examining the questions of ideological choice, the reasons for the spread of market mechanisms and the interests that they serve. It is one that implicitly invites institutions to automatically expand the choice without necessarily having to engage with the underlying normative character of new instruments. While regulatory choice may be a useful lens in some cases and its contribution to the discipline of environmental law has been noteworthy, ${ }^{110}$ thinking about conservation solutions can and should proceed in ways that are more explicitly political. The suggestions to extend this analytical framework to the sphere of inter- and transnational conservation law ${ }^{111}$ however do not demonstrate an awareness of the inherent political-economic disputes enshrined in market mechanisms.

\footnotetext{
${ }^{104}$ Freeman \& Kolstad, n. 98 above, at p. 5.

105 E.g. D. J. Fiorino, The New Environmental Regulation (The MIT Press, 2006); A. Jordan, R.K.W. Wurzel \& A.R. Zito, 'New' instruments of Environmental Governance: Patterns and Pathways of Change,' (2003) 12(1) Environmental Politics, pp. 1-24.
}

106 E.g. R. Greenspan Bell \& C. Russell, 'Environmental Policy for Developing Countries Most Nations Lack the Infrastructure and Expertise Necessary to Implement the Market-based Strategies Being Recommended by the International Development Banks,' (2002) 18(3) Issues in Science and Technology, pp. 63-70; A. Costi, 'Reconciling Environmental Justice and Development in Transition Economies: The Central and Eastern European Reality,' in K. Bosselman \& B. J. Richardson (eds.) Environmental Justice and Market Mechanisms: Key Challenges for Environmental Law and Policy (Kluwer Law, 1999).

107 M. Grubb et al., The Kyoto Protocol: A Guide and Assessment, (Royal Institute for International Affairs, 1999), at pp. 108-9; L. Lohman, 'Marketing and Making Carbon Dumps: Commodification, Calculation and Counterfactuals in Climate Change Mitigation' (2005) 14(3) Science as Culture, pp 203-235, at pp. 204-6.

108 J. Salzman \& J. B. Ruhl, 'Currencies and the Commodification of Environmental Law,' (2000) 53(3) Stanford Law Review, pp. 607-694; J. Salzman, 'Creating Markets for Ecosystem Services: Notes from the Field' (2005) 80 New York University Law Review, pp. 870-961; Freeman \& Kolstad, n. 98 above.

${ }^{109}$ But see D. M. Driesen (ed.) Economic Thought and U.S. Climate Change Policy (MIT Press, 2010); D. Driesen, n. 97 above, at p. 219.

${ }^{110}$ L. Heinzerling, 'The Environment,' in The Oxford Handbook of Legal Studies, P. Cane \& M. Tushnet (eds.) (Oxford University Press, 2003), pp. 701-24; C. Coglianese \& C. Courcy, 'Environmental Regulation,' in The Oxford Handbook of Empirical Legal Research, P. Cane \& H. M. Kritzer (eds.) (Oxford University Press, 2010), pp. 449-68.

111 E.g. R. B. Stewart, 'Instrument Choice,' in D. Bodansky, J. Brunnee. \& E. Hey (eds.) The Oxford Handbook of International Environmental Law (Oxford University Press, 2007), pp. 147-81; Revesz \& Stavins, n. 102 above. 


\subsection{Markets in neoliberalism}

The abovementioned conceptions of market mechanisms can usefully be supplemented by the one constructed by critics of neoliberalism. The latter are a diverse group of scholars from across the social sciences, whose object of confrontation is a term that is notoriously difficult to define. Neoliberalism has become a catch-all term describing a number of approaches, distinct political positions, discursive practices and institutional features across different disciplines. This suggests that neoliberalism should not be thought of as a fixed notion but as 'a loose conglomeration of institutions, ideas and policy prescriptions'.112

Whatever the focus of analysis, critiques of neoliberalism originate from the realization that markets, while neither 'natural' nor 'neutral', represent a key organizing principle of the neoliberal tradition. On this view, the troubling aspect is not so much the fact that free markets underpin economic relations, but their expansion and control over non-economic spheres, coupled with the government's role being restricted to enabling the operation of the markets, rather than providing limitations and guidance to them. ${ }^{113}$ Markets can indeed become an organizational pattern of political and social relations in societies and thus 'a comprehensive mode of governance', determining 'how should we live' and 'who should pay'.114

Building largely on the work of Karl Polanyi, critics of neoliberalism reject the separation of economic relations from broader structures of normative guidance. They lament that society has been led to run as:

an adjunct to the market. Instead of economy being embedded in social relations, social relations are embedded in the economic system...once the economic system is organized in separate institutions, based on specific motives and conferring a special status, society must be shaped in such a manner as to allow that system to function according to its own laws. ${ }^{115}$

According to the critics, neoliberalism and markets are accused of undermining other social processes and relationships. They are viewed as devaluing social justice, solidarity, equality, and mutual care, and nurturing instead relationships that are de-personalized, narrowly individualistic, egoistic and rational. ${ }^{116}$ They are disliked for seeking to supplant the commons and the collective, public values with private property and individualistic, private values of market rationality as the guiding principles of all policy and everyday life. Neoliberalism is

\footnotetext{
112 J. L. Campbell \& O. K. Pedersen, 'Introduction', in J. L. Campbell \& O. K. Pedersen (eds.) The Rise of Neoliberalism and Institutional Analysis (Princeton University Press, 2001), pp. 1-24, at p 3.

113 B. Pokorny et al., 'Market-based Conservation of the Amazonian Forests: Revisiting Win-win Expectations,' (2012) 43 Geoforum, pp. 387-401, at p. 388.

114 N. Castree, 'Neoliberalising Nature: The Logics of Deregulation and Reregulation,' (2008) 40(1)

Environment and Planning A, pp. 131-52, at p. 143.

115 K. Polanyi, The Great Transformation (Beacon Press, 2001), at p. 60.

116 C. Barnett, 'Publics and Markets: What's Wrong with Neoliberalism?,' in S. Smith et al. (eds.) The

Handbook of Social Geography (Sage, 2010), pp- 269-96.
} 
seen as hostile to democracy and the public realm, which encompasses public interest, public services and a collective identity. ${ }^{117}$ The opposition to neoliberalism is foremost a rejection of a general deployment of economic, managerial, technical and seemingly rational discourse as the dominant framework for decision making, and a rejection of a depoliticization of issues.

\subsection{The neoliberalization of nature}

In the field of biodiversity conservation, critiques of neoliberalism as an ideational project and a political programme converge on the utter rejection of the idea of 'pricing nature' and the refusal of efficiency as the driving principle of the market. In their view, putting a value on endangered species and habitat and turning them into marketable assets turns nature into a commodity, which can be exchanged like anything else on the market, and forbids any place or species of their existence on their own right. 118

The neoliberalization of nature is associated also to the process of valuation of nature, being a condition for market transactions. Although ecological economists have made much progress in recent years, biodiversity evaluation remains methodologically challenging. Generally, the production and use of numerical data tends to (radically) simplify ecological and social complexities. ${ }^{119}$ Environmental valuation is also highly culturally or value specific in that the results depend on the conceptions of what constitutes values in society. ${ }^{120}$ For many, the very attempt to crunch unquantifiable values into numbers implicitly represents the imposition of a particular political economy. Therefore, valuations are inherently a matter of bargain or domination, particularly in the case of transnational payments.

Critics further contend that market mechanisms shift morality from deontological to consequential, where conservation practices are not pursued because they are the right thing to do, but because or when they make economic sense. ${ }^{121}$ This new ethics proffers the imagery of nature as a repository of resources rather than as a 'responsibility' under our stewardship. It removes the moral stigma associated with environmental degradation and effectively creates a

117 J. Clarke, 'Dissolving the Public Realm?: The Logics and Limits of Neo-liberalism' (2004) 33(01) Journal of Social Policy, pp. 27-48.

118 Monbiot, n. 56 above.

${ }^{119}$ E.g. E. Cloatre \& N. Wright, 'A Socio-legal Analysis of an Actor-world: The Case of Carbon Trading and the Clean Development Mechanism,' (2012) 39(1) Journal of Law and Society, pp. 76-92; C. Reid, 'Between Priceless and Worthless: Challenges in Using Market Mechanisms for Conserving Biodiversity’ (2013) VOL(ISSUE) Transnational Environmental Law, pp. PAGES.

${ }^{120}$ C. Spash, 'Ecosystems services valuation. Socio-economics and the Environment in Discussion’ (2008) CSIRO Working Paper Series, available at: http://csiro.au/files/files/pjpj.pdf; E. Gómez-Baggethun \& M. RuizPérez, 'Economic Valuation and the Commodification of Ecosystem Services,' (2011) 35(5) Progress in Physical Geography, pp. 613-628.

121 E.g, K. McAfee, 'Selling Nature to Save It? Biodiversity and Green Developmentalism,' (1998) 17(2) Environment and Planning D: Society and Space, pp. 133-54. 
'right to pollute', where pollution is not deplorable but (simply) costs money and can be bought or sold like any other commodity. ${ }^{122}$ It also affects the aim of the policy that governs nature, which is no longer to prevent the degradation of nature, but to do so only when it pays. In theory at least, this can lead some (richer) actors to use nature as they please, regardless of its public benefits.

The ideology of neoliberalism is also criticized for placing emphasis on action rather than reflection, and on means rather than ends. ${ }^{123}$ As such, the purpose of policies concerned with markets is not to minimize the environmental impact, but to continuously maintain a level of economic activity. The inherent conflict between the market rationale and the objective of reducing environmental impact becomes most striking when 'successfully operating markets' result in harmful environmental outcomes. ${ }^{124}$

Perhaps most importantly, the focus on putting market mechanisms into effect pushes attention away from structural changes, which many believe are the only solution to the global problem of biodiversity loss. When market mechanisms are operating, the illusion is sustained that something is being done about environmental protection and that the existing economic framework and institutions allow for environmental progress. The illusion is a distraction from the fact that ecological limits or 'planetary boundaries' represent physical limitations to any human activity, including economy. ${ }^{125}$ Demands for radically different economic trajectories, such as to keep oil, gas and coal in the ground, rather than offsetting their use, do not materialize through the operation of market mechanisms. An alternative to market mechanisms could start from considerations about ecological limitations and adjust consumption patterns accordingly.

\section{CONCLUSION: IDEOLOGY IN TRANSNATIONAL ENVIRONMENTAL LAW}

This article set out to foreground transnational market mechanisms for biodiversity and to encourage legal interest in them. Biodiversity markets have emerged as efforts to provide more pragmatic solutions to the biodiversity crisis. Even though market mechanisms are highly contested tools for biodiversity conservation, they have been endorsed both by the key conservation institutions and the epistemological framework.

\footnotetext{
122 Winter, n. 10 above.

123 J. H. Clarke \& J. E. Newman, The Managerial State: Power, Politics and Ideology in the Remaking of Social Welfare (Sage, 1997), at p. xii.

124 E.g. J. Dehm, 'Tricks of Perception and Perspective: The Disappearance of Law and Politics in Carbon Markets; Reading Alexandre Kossoy and Phillippe Ambrosi, "State and Trends of the Carbon Market 2010", 2011 7(2) Macquarie Journal of International and Comparative Environmental Law, at pp. 1-18 .

125 J. Rockström et al., 'Planetary Boundaries: Exploring the Safe Operating Space for Humanity - Stockholm Resilience Centre,' (2009) 14(2) Ecology and Society, pp. 32-8.
} 
One influential account has dubbed critiques of market mechanisms for biodiversity as 'irrational fears', which may be overcome by switching terminology away from the market. ${ }^{126}$ The suggestion correctly points out that the principal dispute between proponents and opponents does not lie in the label itself and that there are inconsistencies in various conceptions of the market. Indeed, the concept is a construct that is not built on a common understanding and a standardized commodity, and yet many refer to the same term assuming that its meaning is agreed.

However, equally irrational as insisting on an ambiguous term is to believe that semantic solutions would eliminate deep disputes over political-economic development trajectories and epistemological differences between different actors involved in the global conservation discourses. Competing views on 'market mechanisms' (or any other name we may call them) represent very real clashes of morality, power relations and worldviews which have plagued environmental politics for decades. The discussions on the technicalities are incapable of overcoming the divides between pro- and anti-market advocates, as they concern fundamental questions of ideologies.

Viewing markets through the eyes of those critical of the market ideology ventures into a seemingly irrational but a perfectly legitimate opposition to the regulation propounded through markets, which reject the imagery of the world as a marketplace being extended to the rapport between human and nature and the altering of social relationships between different users of that nature. These critiques must be understood as an appeal for a more intuitive relationship with nature, and a societal progress that would recognize the limits of a growth-based economic paradigm. The presentation of market mechanisms as a practical measure to slow the destruction is deeply frustrating for those who see them as perpetuating the very disconnection from nature and forestalling the development of real alternatives, addressing the deeper causes of the biodiversity crisis.

The theoretical aspect to take away from the debate generated by the critics of neoliberalism concerns the choice of the framework for the conceptualization of transnational environmental law. The conception of transnational legal space as a problem of regulation and regulatory choice seems to legitimize the choice for markets because the conventional portrayal of the goal of regulation as 'correcting market failures' construes regulation as supportive or even constitutive of markets. This narrative is unreceptive for epistemologies, which build upon notions different from those of markets and associated concepts, such as those of the global South that pursue the rights and integrity of Mother Nature, highlighting significance of spirituality, and explicitly rejecting market solutions. ${ }^{127}$

126 Wunder \& Vargas, n. 91 above.

127 See, e.g., B. de Sousa Santos, 'Introducción: Las epistemologías del Sur,' Formas-Otras: Sabel, nombrar, narrar, hacer (CIDOB Ediciones, 2011-12), pp. 9-22. Note also the World People's Conference on Climate Change and the Rights of Mother Earth, held in June 2012 in Cochabamba, Bolivia. 
The future efforts in the conceptualization of transnational environmental law must be careful to not suppress certain epistemological positions by the very choice of the framework for thinking about solutions. The regulatory framework, which has characterized much of the contemporary discussions in transnational law is foremost a functional project. However, denying the ideological disputes about biodiversity market mechanisms would be unproductive and unwise: legal analysis needs to re-establish its interest beyond that of the regulation literature if it is to account for the proliferating movements around the world in favour of a reasserted normative guidance for the markets 128 and against the current process -of marketing the market.

${ }^{128}$ M. Levien \& M. Paret, 'A Second Double Movement? Polanyi and Shifting Global Opinions on Neoliberalism' (2012) 27 International Sociology, pp. 724-44. 